\title{
Ouvidoria é democracia
}

\section{Ombudsmanship and listening as democracy}

\section{La defensoría es democracia}

Luis Narciso Bork Vega ${ }^{1}$

O trabalho do ombudsman, do defensor del pueblo, dos ouvidores é fundamental para o desenvolvimento democrático de um país e o foi especialmente para o Chile quando, a partir de 1990, recuperou a democracia, depois da ditadura de Pinochet.

O Capítulo Chileno del Ombudsman congrega tanto ouvidores públicos quanto de empresas privadas e acadêmicos das áreas de políticas públicas, direito e comunicação e buscamos socializar essa ideia na sociedade civil. Esperamos que até 2010 venhamos a ter um ombudsman nacional, que hoje ainda não temos.

O ombudsman é importante para nós porque, como em todo o mundo moderno, a democracia é um processo que vai se enriquecendo aos poucos. Ela não está pronta, mas se faz a cada dia, a cada mudança econômica, política ou social. É indispensável que as constituições nacionais garantam os direitos fundamentais do ser humano, mas também é imprescindível que haja mecanismos de controle e de aplicação e, sobretudo, de proteção desses direitos no País.

A existência da figura do ombudsman, por si só, permite que o cidadão se sinta mais seguro em relação aos seus direitos. Essa instituição, que deve ser independente do Estado, tem de corresponder a essa expectativa tão elementar por parte das pessoas para que haja cidadania. Neste mundo globalizado - se

1 Advogado e professor de Direito Administrativo, é vice-reitor da Universidad de Playa Ancha, em Valparaiso (Chile) e vice-presidente do Capítulo Chileno del Ombudsman. 
bem que eu prefira falar "mundializado", pois a globalização está muito ligada a aspectos econômicos -, os temas que preocupam a uns preocupam a todos, são também coletivizados. É o que acontece com os grandes debates como os relativos ao meio ambiente, à discriminação das minorias e aos temas mais localizados que passam a dialogar com esses mais amplos. Os serviços públicos, que, para serem mais eficientes, estão sendo privatizados, muitas vezes não correspondem à satisfação dos cidadãos.

Por tudo isso, se requer que uma instância de poder, com autonomia, zele pelo bem-estar do cidadão e pelo bom exercício do serviço público em benefício do cidadão, que é muitas vezes incapaz de, por si mesmo, fazer valer os seus direitos.

Uma democracia não é apenas um sistema no qual alguém pode se eleger ou ser eleito. Isso simplesmente seria uma autocracia. Democracia autêntica implica a plena vigência dos direitos humanos, a existência de mecanismos eficientes e eficazes, a responsabilidade da administração e de seus funcionários... E permanente exercício do controle. Tudo isso respeitando o ordenamento jurídico, o princípio da legalidade. 